\title{
Editorial: new section
}

\section{New section: innovators and transformers - lessons, opportunities and cocreations in logistics and supply chain management}

Supply chain management at a crossroad - the need for innovators and transformers

Because of the coronavirus disease 2019 (COVID-19) pandemic there is a lot less of a need to explain the importance of logistics and supply chain management (LSCM) for business and society. The truth of the matter however is that there is likely a fair amount of relearning of lessons from supply chain risk management research and new learning taking place in the context of the pandemic. Well-known techniques such as reducing reliance on a few rationalized sources of supply, balancing global sourcing with local responsiveness and more agile supply capability once widely recommended (Handfield et al., 2020; van Hoek, 2020a, b) may still be relevant but they require innovative adaptation as the world changes rapidly. Besides the COVID-19 pandemic, political tensions and trade wars have driven supply chain leaders to rethink and transform the supply chains they built up in the past. Change, innovation and transformation are critically needed but may be hard to achieve (van Hoek et al., 2010). This illustrates how there is a need to learn from pioneers (as called for by Ferdows, 2018) and thought leaders (as called for by Waller et al., 2012) as they confront emerging and major challenges and for the pioneers and thought leaders to cocreate a new future of supply chain management.

As our discipline becomes of a certain age and maturity, several top journals are celebrating anniversaries. For instance, the Journal of Business Logistics $(J B L)$ turned 40, the Journal of Purchasing and Supply Management turned 25 and this journal, International Journal of Physical Distribution and Logistics Management (IJPDLM), is turning 50. There is no lack of research opportunities ahead of us. The field has developed ideas, concepts, frameworks and theories in areas such as integration, collaboration, digitization, data analytics, risk and resilience, corporate social responsibility, sustainable supply chain management, agility, customer service, innovation, talent management, supply chain finance, omnichannel logistics (Stevens and Johnson, 2016; Goldsby et al., 2019; Spekman and Davis, 2016; Van Hoek et al., 2020; Stank et al., 2019; Carter et al., 2019; Bals et al. 2019; Gelsomino et al., 2016). The big question is whether academic research is sufficiently contributing to the innovation and transformation of supply chains into the future? Do pioneers and leaders in industry read academic journal papers and get inspired? Can academic researchers achieve greater thought leadership to inspires others and inform pioneers, so they can successfully transform the supply chain?

\section{Why a new section on innovators and transformers?}

Stentoft and Rajkumar (2018) suggest that there is little dissemination of academic research into industry at present. Industry leaders learn new knowledge through accessible information. The typical 10,000-12,000 words academic research journal papers are less likely to inspire them. It is often difficult to translate academic research meaningful practical implications, even though they utilize advance theories and rigorous methodologies. There has been recognition that "the current business research model is unsuitable" and the need to "encourage faculty to product credible research that is useful to society" (Glick et al., 2018). In the context of the pandemic the Financial Times reported a "shift towards practice-based research, with professors working alongside companies directly with detailed data to solve the challenges they face, develop approaches and test them in practice "[1]. When academic

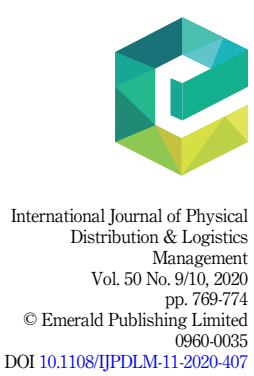


IJPDLM

$50,9 / 10$

770

researchers can better understand emerging and important phenomena, problems and opportunities in society, they can then conduct research that is useful to the society. Often industry leaders, managers and pioneers that are transforming supply chains with new ideas are more capable of describing problems and opportunities they face better than an academic researcher, even though they do not theorize and apply rigorous methodologies. Without understand the real-life experience, and lessons learned among these practitioners, academic research can only play catchup instead of assuming a thought leadership role.

LSCM researchers can meaningfully advance the science of our discipline for greater impact on society and business:

To deliver on our promise to "advance knowledge" and help realize the promise of emerging technologies, supply chain education will need to change. Yesterday's skill set will not be competitive in tomorrow's world. At some point, we might want to explore how JBL can more effectively transfer knowledge into practice. This capability may be the key to whether the Academy can provide a societal ROI and stay ahead of the obsolescence curve (Fawcett and Waller, 2015a, b).

This takes us back to the roots of our discipline. From the inaugural editorial of $J B L$ :

The Journal will attempt to present material at the level of the "thoughtful businessman" and we will carefully attempt to avoid the trap of presenting sophisticated quantitative methodology in a manner whereby a limited number of highly quantitatively skilled individuals carry on a conversation with an equally limited number of high quantitatively skilled individuals using the Journal as the medium. We are committed to developing a journal which is responsive to the needs of the readership and the discipline. (LaLonde, 1978).

This echoes what CSCMP Supply Chain Hall of Famer Henry Ford once said:

I believe in 100\% Theory and 100\% Practice. Theory without practical application is futile. Ford in an interview with Sylvester Vierick, 8/5/1928, available on the Henry Ford Museum website.

Indeed the editorial approach of IJPDLM has continued to recognize how LSCM can benefit from research that is directly and immediately applicable to business practice (Autry, 2012; Busse, 2014); like many other LSCM journals, IJPDLM aims to "provides business practitioners, policy makers, consultants and academics with leading edge information and discussion of current developments in the field. It facilitates the interchange of information among stakeholders across the globe while providing a platform for new insights on problems and techniques related to all facets of supply chain management." (https://www. emeraldgrouppublishing.com/journal/ijpdlm\#aims-and-scope).

Practical relevance can be used to drive theoretical advancement (Ellinger and Chapman, 2016). Practical relevance is achieved when the results of scientific research has a meaningful connection with management practice and when it is accessible; it inspires actionable solutions; it informs managerial decisions (Nicolai and Seidl, 2010). Additionally, Svanberg (2020) suggests as screens for practically relevant research: is it a problem faced by practitioners, is it timely, important, implementable, nonobvious, novel and not too costly. And techniques suggested to ensure relevance include seeking practitioners' input in framing the research problem, involving practitioners throughout the research process and seeking feedback from practitioners. Stentoft and Rajkumar (2018) suggest an alternative research and editorial strategy to improve creativity and impact, including for example practical papers that are developed based upon current practice among organizations and on practitioners' prospects to provide relevant solutions for LSCM issues. Practically relevant research may be more interdisciplinary (Sanders et al., 2016; Wortmann and Jagdev, 2020) and boundary spanning (Murphy et al., 2019; Dekker et al., 2019). Touboulic et al. (2020) call for critically engaged research; 
Within critical engaged research, the traditional power relations between researcher and participants are not taken for granted and the emphasis shifts toward [...] engagement with participants, cocreation, and reflexivity. [...] Critical engaged research provides an opportunity to analyze SC phenomena in the context within which they are constructed and to present a richer picture of the empirical world. [...] The process by which supply chains are being transformed are complex and not yet fully understood, engaged research presents opportunities to elaborate our knowledge

Based upon the greater recognition of the importance of supply chain to business and society at present, the founding fathers of our discipline may be able to declare victory against what they set out to do 50+ years ago. Academically speaking our top journals have not only earned their stay; they have also provided opportunity for scholars to get published and promoted based upon their work. However, we may risk drifting away from our roots of focusing on relevance, collaborating with industry, and cocreating and we may be putting the future lifeblood of ideas and their societal contributions at risk. In these times of change LSCM researchers should be researching and developing new knowledge to support supply chain innovation and transformation as it happens. And as the world is changing given the threats the climate crisis, poverty, hunger and inequality, LSCM researchers can step up in their research to make a greater contribution to achieving UN sustainable development goals. To quote Henry Ford once again:

The only true test of values, either of men or of things, is that of their ability to make the world a better place in which to live. (Ford News, 10/1/1924).

\section{The aim of the new section on innovators and transformers}

IJPDLM is launching this new special section focused on innovators and transformers in industry and academia. We have founding fathers and incredible innovations to build upon and to advance. Over the years many of our disciplines founding fathers and academic pioneers have been honored with CSCMP Distinguished Service Awards and other awards such as the IPSERA lifetime achievement award or EUROMA fellowships. We can stand on the shoulders of the pioneering work of those that helped us get started; Bowersox, LaLonde, Christopher, Cole, and Lambert and those that helped us develop and grow including Mentzer and Waller. They pioneered relevant and transformative scholarship that helped create and build the discipline.

Cocreation is another central tenant of the special section. To better understand real-word supply chain innovation and transformation, academics and practitioners are encouraged to cocreate research. For example, the CSCMP Supply Chain Hall of Fame brings together industry leaders that have invented hallmarks of supply chain at present, e.g. intermodal, the assembly line, the barcode, lean manufacturing. We can continue to learn from them and be inspired by them. More importantly, by working with industry leaders, we learn to research real-world problems. Working with industry can create a deeper understanding of current problems and opportunities and develop more meaningful research that can advance theories.

But perhaps most importantly, the focus on innovators and transformers may help us tackle the supply chain challenges for the next 50 years. From sustainability to future-proof talent management, from digitization to humanitarian logistics, from ESG's to open source innovation, from automation to replace logistics jobs to creating meaningful LSCM jobs of the future. We welcome papers that will capture lessons learned from the greatest innovators and transformers to date as well as the opportunities to build upon these in research and industry. We welcome papers that introduce innovations and practices that can transform the supply chain into the future and inspire the research that will help us get there. And we welcome papers that can inform the future model for relevant and impactful research and scholarship, that can help future-proof supply chain education and the future of work in supply chains. 
IJPDLM

$50,9 / 10$

Specifically, we welcome viewpoint and perspective papers, papers cowritten with and by managers, papers that offer perspective on key innovations and learn from transformative innovations to inspire further research and innovation (rather than present the finished research).

We hope that this new special section will contribute to the potential of supply chain leaders to help make the world a better place, to inspire and inform the turning of knowledge and research into action for the supply chain of the future.

\section{The scopes of the new section}

The new section welcomes short articles (4,000-6,000 words including figures, tables, references and appendix) aiming to benefit the SCM research agenda, the SCM field and societal impact of SCM. Another main role of this section is to drive and stimulate research that can be published as full research articles later in regular or special issues. The articles may

(1) Detail the history, lessons learned and future potential of breakthrough in supply chain innovations and transformative leadership accomplishments in industry and/ or research and their impact on the supply chain.

(2) Detail cocreation between business practitioners and academics to drive innovation in the logistics and supply chain management field with transformative potential.

(3) Delineate emerging problems, challenges, innovations in the logistics and supply chain management field that hold transformative potential and represent substantial future research opportunity.

(4) Involve real-world developments and challenges that are best served by an interdisciplinary approach and as such represents substantial future research opportunity.

\section{What the new section is NOT for}

The new section is NOT for the following types of regular research articles:

(1) Regular or full research articles involve the construction or testing of a model or framework, testing of hypotheses, market research or surveys, empirical, scientific or clinical research.

(2) Literature review articles that analyze and/or critique existing literature in a subject area.

(3) Viewpoint articles that discuss the opinion or interpretation of the authors about a topic (unless invited by the editors).

(4) Technical and modeling articles that describe and evaluate technical products, processes or services.

(5) Mathematical modeling articles.

\section{How to submit the manuscript?}

Articles can be submitted to the special section anytime. The initial aim is to publish three-six articles annually. The articles will be double-blind reviewed and subjected to the same quality expectations as those submitted to regular issues. A short and conscience description of methods and data is desirable for articles involved empirical data. You are welcome to contact the section editors if you have any question. 
Section editors

Professor Remko van Hoek

The Sam M. Walton College of Business, University of Arkansas, USA.

Email: rvanhoek@walton.uark.edu

Mr David Loseby

Director of Procurement, Rolls-Royce PLC., UK.

Email: d.loseby@uea.ac.uk

Prof. Chee Yew Wong

Leeds University Business School, University of Leeds, UK.

Email: c.y.wong@leeds.ac.uk

Note

1. https:/www.ft.com/content/d78ae36f-be2f-4560-ab0f-21b22c702e21

\section{Remko van Hoek, David Loseby and Chee Yew Wong}

\section{References}

Autry, C.W. (2012), "Editorial to first annual special issue on 'Managerially relevant logistics models", International Journal of Physical Distribution and Logistics Management, Vol. 42 No. 2.

Bals, L., Schulze, H., Kelly, S. and Stek, K. (2019), "Purchasing and supply management (PSM) competencies: current and future requirements", Journal of Purchasing and Supply Management, Vol. 25 No. 5.

Busse, C. (2014), "Striving for appropriate forms of relevance through problem-driven research", International Journal of Physical Distribution and Logistics Management, Vol. 44 No. 10.

Carter, C., Hatton, M.R., Wu, C. and Chen, X. (2019), "Sustainable supply chain management: continuing evolution and future directions", International Journal of Physical Distribution and Logistics Management, Vol. 50 No. 1, pp. 122-146.

Dekker, H., Donada, C., Mothe, C. and Nogatchewsky, G. (2019), "Boundary spanner relational behavior and inter-organizational control in supply chain relationships", Industrial Marketing Management, Vol. 77, pp. 143-154.

Fawcett, S.E. and Waller, M.A. (2015a), "Designing the supply chain for success at the bottom of the pyramid", Journal of Business Logistics, Vol. 36 No. 3, pp. 233-39.

Fawcett, S.E. and Waller, M.A. (2015b), "The quest for societal ROI in the midst of the perfect storm: can SCM set the standard for twenty-first century business education?", Journal of Business Logistics, Vol. 36 No. 1, pp. 1-8.

Ferdows, K. (2018), "Keeping up with growing complexity of managing global operations", International Journal of Operations and Production Management, Vol. 38 No. 2, pp. 390-402.

Gelsomino, L.M., Mangiaracina, R. and PeregoTumino, A.A. (2016), "Supply chain finance: a literature review", International Journal of Physical Distribution and Logistics Management, Vol. 46 No. 4.

Glick, W.H., Tsui, A. and Davis, G.F. (2018), The Moral Dilemma of Business Research, BizEd, pp. 32-37.

Goldsby, T.J., Zinn, W., Closs, D.J., Daugherty, P.J., Stock, J.R., Fawcett, S.E. and Waller, M. (2019), "Reflections on 40 years of the journal of business logistics: from the editors", Journal of Business Logistics, Vol. 40 No. 1, pp. 4-29.

Handfield, R.B., Graham, G. and Burns, L. (2020), "Corona virus, tariffs, trade wars and supply chain evolutionary design", International Journal of Operations and Production Management. 
IJPDLM $50,9 / 10$

Murphy, W.H., Gölgeci, I. and Johnston, D.A. (2019), "Power-based behaviors between supply chain partners of diverse national and organizational cultures: the crucial role of boundary spanners' cultural intelligence", Journal of Business and Industrial Marketing, Vol. 35 No. 2, pp. 204-218.

Nicolai, A. and Seidl, D. (2010), "That's relevant! Different forms of practical relevance in management science”, Organization Studies, Vol. 31 Nos 9/10, pp. 1257-1285.

Sanders, N.R., Fugate, B.S. and Zacharia, Z.G. (2016), "Interdisciplinary research in SCM: through the lens of the behavioural theory of the firm", Journal of Business Logistics, Vol. 37 No. 2, pp. 107-112.

Spekman, R. and Davis, E.W. (2016), “The extended enterprise: a decade later”, International Journal of Physical Distribution and Logistics Management, Vol. 46 No. 1, pp. 43-61.

Stank, T., Esper, T., Goldsby, T.J., Zinn, W. and Autry, C. (2019), "Toward a Digitally Dominant Paradigm for twenty-first century supply chain scholarship", International Journal of Physical Distribution and Logistics Management, Vol. 49 No. 10, pp. 956-971.

Stentoft, J. and Rajkumar, C. (2018), "Balancing theoretical and practical relevance in supply chain management research", International Journal of Physical Distribution and Logistics Management, Vol. 48 No. 5, pp. 504-523.

Stevens, G.C. and Johnson, M. (2016), "Integrating the supply chain 25 years on”, International Journal of Physical Distribution and Logistics Management, Vol. 46 No. 1, pp. 19-42.

Svanberg, M. (2020), "Guidelines for establishing practical relevance in logistics and supply chain management research", International Journal of Physical Distribution and Logistics Management, Vol. 50 No. 2, pp. 215-232.

Touboulic, A., McCarthy, L. and Matthews, L. (2020), "Re-imaging supply chain challenges through critical engaged research", Journal of Supply Chain Management, Vol. 56 No. 2, pp. 36-51.

van Hoek, R. (2020a), "Research opportunities for a more resilient post-COVID-19 supply chain closing the gap between research findings and industry practice", International Journal of Operations and Production Management, Vol. 40 No. 4, pp. 341-355.

van Hoek, R. (2020b), "Responding to COVID-19 supply chain risks - insights from supply chain change management, total cost of ownership and supplier segmentation theory", Logistics, Vol. 4 No. 4.

van Hoek, R., Johnson, M., Godsell, J. and Birtwistle, A. (2010), "Changing chains: three case studies of the change management needed to reconfigure European supply chains", The International Journal of Logistics Management, Vol. 21 No. 2, pp. 230-250.

Van Hoek, R., Sankararaman, V., Udesen, T., Geurts, T. and Palumbo-Miele, D. (2020), "Where we are heading and the research that can help us get there - executive perspectives on the anniversary of the journal of purchasing and supply management", Journal of Purchasing and Supply Management, Vol. 26 No. 3, p. 100621.

Waller, M.A., Fawcett, S.E. and van Hoek, R. (2012), "Thought leaders and thoughtful leaders: advancing logistics and supply chain management", Journal of Business Logistics, Vol. 33 No. 2, pp. 75-77.

Wortmann, H. and Jagdev, H. (2020), "40 years computers-in-industry: applied interdisciplinary research”, Computers in Industry, Vol. 123, p. 103315.

\section{Further reading}

Lambert, D.M. (2019), "Rediscovering relevance", International Journal of Logistics Management, Vol. 30 No. 2, pp. 382-394.

Mentzer, J.T. (2008), "Rigor versus relevance: why would we choose only one?", Journal of Supply Chain Management, Vol. 44 No. 2, pp. 72-77. 